\section{Anesthetist: N.B.}

Required for the Doctor Georges-L. Dumont Regional Hospital, Moncton. Candidate will join 5 other anesthetists on fee-for-service basis.

Settlement grant, CME grant, moving expense and other benefits negotiable for a 3 year contract. A 338 bed tertiary care hospital, in a city of 80,000 people.

Candidate must have a working knowledge of French or be ready to learn within a year.

Apply to:

Medical Director

Dr. Georges-L. Dumont Hospital

330 Archibald Street

MONCTON, NEW BRUNSWICK

E1C $2 Z 3$

Telephone (506) 858-3231

\section{Anesthétiste: N.-B.}

Hôpital Docteur Georges-L. Dumont, Moncton; 338 lits, TACO, Médecine nucléaire et services tertiaires. Recherche anesthésiste pour se joindre à une équipe de cinq.

Bénéfices: prime d'établissement et prime d'EMC renouvelable pour trois ans, frais de déménagement, autres bénéfices négociables.

Doit parler français ou disposé à l'apprendre en dedans d'un an. Faire parvenir votre curriculum vitae:

Directeur médical

Hôpital Dr G.-L. Dumont

330, rue Archibald

MONCTON (Nouveau-Brunswick)

E1C $2 Z 3$

Téléphone (506) 858-3231

\title{
CLINICAL FELLOWS IN ANESTHESIA
}

The Department of Anesthesia, Mount Sinai Hospital, is a tertiary referral centre affiliated with the University of Toronto. We provide coverage for all major surgical services except neuro-surgery and open heart surgery. In addition, we are a major obsterrical centre, including high risk referral.

Applicants must possess or be able to obtain a general licence for practice in the province of Ontario and have obtained or be eligible for the FRCP(C).

The position will be the provision of clinical anesthesia as well as the participation in medical student and residency education. It will not involve any night or weekend coverage.

These positions are available immediately. Applications with the names of 3 references and a copy of Cumiculum Vitae should be sent to:

Dr. G. Urbach

Department of Anesthesia, Mount Sinai Hospital

600 University Avenue, Toronto, Ontario M5G $1 \times 5$

\section{CERTIFIED ANAESTHETIST}

Required for busy 300 plus, bed General Hospital in Southwestern Ontario. No obstetrics. Fee for service. Reply with particulars and references to:

\section{Dr. Paul Shum}

Chief, Department of Anaesthesia

Windsor Western Hospital Centre

1453 Prince Road, Windsor, Ontario N9C 3Z4

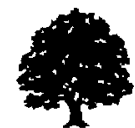

